\title{
SINTESIS ESTER-C SEBAGAI SENYAWA ANTIOKSIDAN MENGGUNAKAN BIOKATALIS ENZIM LIPASE/ZEOLIT ALAM
}

\author{
Nanik Wijayati ${ }^{*}$, Siti Anisa Rohmah ${ }^{1}$, Supartono Supartono ${ }^{1}$ \\ ${ }^{1}$ Jurusan Kimia Fakultas Matematika dan Ilmu Pengetahuan Alam, \\ Universitas Negeri Semarang \\ *email: nanikanang@gmail.com
}

\begin{abstract}
Abstrak
Imobilisasi enzim lipase merupakan metode yang digunakan untuk meningkatan daya tahan enzim terhadap perubahan lingkungan dan penggunaan secara berulang. Penelitian mengenai imobilisasi enzim lipase dari jamur tiram putih (Pleurotus ostreatus) telah dilakukan dengan metode entrapment (penjebakan, penjeratan) menggunakan zeolit alam teraktivasi dan larutan gel $\mathrm{NaF}$. Waktu pengadukan optimum yang diperoleh dalam imobilisasi enzim lipase ialah selama 3 jam dengan nilai aktivitas lipase sebesar 4,24 U/mL dan enzim loading sebesar 63,07\%. Enzim lipase terimobilisasi yang diperoleh diaplikasikan dalam uji stabilitas berulang pada sintesis ester-C. Hasil sintesis dianalisis menggunakan instrument FT-IR dan HPLC.
\end{abstract}

Kata kunci: enzim, lipase, imobilisasi, ester-C

\begin{abstract}
Immobilized lipase enzyme is the method used to improve the durability of enzymes to changes in the environment and use repeatedly. Research on the lipase enzyme immobilization of white oyster mushroom (Pleurotus ostreatus) has been done by the entrapment method using activated natural zeolites and $\mathrm{NaF}$ gel solution. The optimum stirring time obtained in immobilized lipase is for 3 hours with a value of lipase activity of $4.24 \mathrm{U} / \mathrm{mL}$ and enzyme loading of $63.07 \%$. Immobilized lipase enzyme obtained in the stability tests repeatedly applied to the synthesis of ester-C. Synthesis results were analyzed using FT-IR instrument and HPLC.
\end{abstract}

Keywords: enzymes, lipase, immobilization, ester-C

\section{Pendahuluan}

Antioksidan merupakan suatu aditif yang penting dalam bahan makanan, kosmetik, dan obat-obatan. Aditif ini berfungsi sebagai pengawet dan mencegah kerusakan produk akibat pembentukan radikal bebas. Vitamin $\mathrm{C}$ (L-asam askorbat) bekerja sebagai antioksidan alami dengan kelarutan tinggi dalam air, namun adanya sifat hidrofilik mampu mengurangi efektivitas dalam menstabilkan lemak dan minyak (Song and Wei, 2002). Masalah stabilitas tersebut dapat diatasi dengan mensintesis senyawa ester-C (ester askorbil asam lemak) yang merupakan turunan dari vitamin C (Costa et al., 2014).Ester-C memiliki sifat yang mirip dengan vitamin $\mathrm{C}$ sebagai antioksidan (Spiclin et al., 2001), serta memiliki kelarutan yang tinggi dalam lemak dan minyak (Eitenmiller and Landen, 2010). Sintesis ester $\mathrm{C}$ melalui reaksi enzimatik mempunyai banyak keuntungan bagi produsen maupun konsumen (Treichel et al., 2010). 
Penggunaan enzim lipase sebagai biokatalisator dalam sintesis ester-C karena spesifitas, regioselektivitas dan efektivitasnya yang tinggi pada kondisi ringan sehingga dapat mencegah oksidasi vitamin $\mathrm{C}$ dan esternya selama reaksi (Kidwai et al., 2009). Meskipun demikian, Nisha et al. (2012) menyatakan bahwa lipase mempunyai berbagai keterbatasan, diantaranya ialah ketidakstabilan enzim, sensitivitas yang tinggi terhadap perubahan lingkungan dan biaya penggunaan enzim yang mahal. Kelemahan enzim dapat diatasi menggunakan metode imobilisasi yang mampu memperbaiki kestabilan enzim dan kemampuan dalam penggunaan kembali pada proses selanjutnya, sehingga dapat mengurangi biaya penggunaannya. Oleh karena itu, pada penggunaan enzim lipase sebagai biokatalis dalam sintesis ester-C perlu dilakukan imobilisasi enzim untuk meningkatkan daya tahan terhadap perubahan lingkungan dan menjaga kestabilan pada reaksi berulang.

\section{Metode Penelitian \\ Alat dan Bahan}

Alat yang digunakan dalam penelitian ini ialah sentrifuge (G.P. Series), Pengaduk magnet multi, spektrofotometri UV-Vis (Shimadzu VU mini 1240), shaking incubator (VS-8480), tube furnace (79400), Infra-red spectrometer (FT-IR Shimadzu-8201 PC), High Pressure Liquid Chromatography (Shimadzu LC-20AD).

Bahan yang digunakan dalam penelitian ini ialah jamur tiram putih (Pleurotus ostreatus), buffer phosphate $\mathrm{pH} 8$, zeolit alam (Chemmix Pratama), Sodium Florida, minyak VCO, Sodium Hidroksida, nheksana, Etanol (97\%), indikator pp, Bovine Serum Albumine (BSA), reagen biuret, kloroform, Asam Klorida (37\%), Sitopharm Asam Askorbat, dan kertas saring.

\section{Prosedur Penelitian \\ Imobilisasi enzim lipase}

Jamur tiram putih diblender dengan menambahkan buffer phosphate $\mathrm{pH} 8$ sampai terbentuk bubur jamur tiram. Supernatan diperoleh dari hasil sentrifus pada $350 \mathrm{rpm}$ selama 20 menit. Pada proses imobilisasi enzim, $30 \mathrm{~mL}$ larutan enzim lipase dicampurkan ke dalam $3 \mathrm{~mL}$ larutan gel $\mathrm{NaF}$ dan $9 \mathrm{~g}$ zeolit alam teraktivasi. Campuran diaduk menggunakan stirrer pada temperatur $10{ }^{\circ} \mathrm{C}$ dengan variasi waktu pengadukan selama 1, 2, 3, 4, dan 5 jam.

\section{Uji aktivitas enzim lipase}

Aktivitas enzim lipase terimobil dianalisis menggunakan metode volumetri dengan menambahkan enzim lipase terimobilisasi ke dalam campuran minyak VCO dalam n-heksana. Campuran diinkubasi pada temperatur $50{ }^{\circ} \mathrm{C}$ dengan kecepatan $150 \mathrm{rpm}$ selama 30 menit. Campuran dititrasi menggunakan larutan $\mathrm{NaOH} . \mathrm{Satu}$ unit (U) aktivitas lipase didefinisikan sebagai jumlah enzim lipase

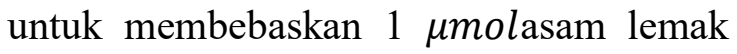
per menit (Karkhane et al., 2012).

\section{Penentuan enzim loading}

Penentuan enzim loading dilakukan dengan cara mengetahui konsentrasi enzim lipase sebelum diimobilisasi dan sesudah diimobilisasi. Konsentrasi enzim diperoleh dengan memplotkan absorbansi sampel pada persamaan regresi dari kurva kalibrasi standar albumin.Absorbansi diukur menggunakan UV-Vis pada panjang gelombang $540 \mathrm{~nm}$.

\section{Sintesis ester-C dan uji stabilitas berulang}

Sintesis dilakukan dengan menambahkan serbuk enzim lipase terimobil, asam askorbat dan minyak VCO dengan pelarut kloroform. Campuran diaduk pada temperatur $50^{\circ} \mathrm{C}$ dengan kecepatan $150 \mathrm{rpm}$ selama 6 jam. Residu dicuci menggunakan larutan $\mathrm{NaCl}$ dan pelarut untuk digunakan kembali sebagai biokatalis dalam sintesis ester-C selanjutnya. Hasil sintesis yang diperoleh dikarakterisasi menggunakan FT-IR dan HPLC. 


\section{Hasil dan Pembahasan}

Aktivitas Enzim Lipase

Uji aktivitas enzim lipase terimobilisasi dilakukan dengan tujuan untuk mengetahui dan membandingkan aktivitas enzim lipase bebas dan enzim lipase terimobilisasi secara entrapment menggunakan zeolit alam teraktivasi. Hasil aktivitas katalitik pada reaksi hidrolisis minyak VCO yang dihasilkan disajikan pada Tabel 1.

Tabel 1. Nilai aktivitas enzim lipase

\begin{tabular}{ccccc}
\hline No. & $\begin{array}{c}\text { Nama } \\
\text { enzim }\end{array}$ & \multicolumn{2}{c}{$\mathrm{NaOH} 0,05 \mathrm{M}$} & Aktivitas \\
& & Sampel & blanko & $(\mathrm{U} / \mathrm{mL})$ \\
\hline 1. & EB & 1,75 & 0,90 & 1,39 \\
2. & EI1 & 1,60 & 0,40 & 1,96 \\
3. & EI2 & 2,35 & 0,30 & 3,34 \\
4. & EI3 & 2,95 & 0,35 & 4,24 \\
5. & EI4 & 0,75 & 0,30 & 0,73 \\
6. & EI5 & 0,65 & 0,30 & 0,57 \\
\hline
\end{tabular}

Keterangan:

$\mathrm{EB}=$ enzim bebas, EI1 = enzim imobil selama 1 jam, EI2 = enzim imobil selama 2 jam, dst.

Aktivitas enzim pada enzim lipase bebas sebesar 1,39 U/ mL. Waktu pengadukan pada proses imobilisasi enzim yang paling optimum ialah selama 3 jam dengan menghasilkan aktivitas katalitik sebesar 4,24 U/ mL. Adanya perbedaan hasil aktivitas pada enzim lipase sebelum dan sesudah diimobilisasi diduga dari perbedaan daya tahan terhadap temperatur yang digunakan pada saat pengujian.Pada temperatur yang terlalu tinggi, enzim lipase bebas akan mengalami denaturasi protein yang dapat mengubah konformasi struktur molekul dan mengganggu bagian sisi aktif enzim, sehingga enzim kehilangan sifat katalitiknya (Amalia et al., 2013). Sedangkan pada enzim lipase terimobilisasi, kerusakan yang terjadi akibat perubahan lingkungan akan mengalami keterlambatan karena adanya perlindungan dari matriks zeolit.

\section{Persentase Enzim Loading}

Penentuan enzim loading dilakukan untuk mengetahui besarnya enzim lipase yang berhasil terimobilisasi menggunakan metode entrapment dalam support zeolit (Parthu, 2012). Enzim lipase yang terjerat dalam pori-pori zeolit akan berinteraksi membentuk ikatan hidrogen akibat adanya kontak antara atom oksigen pada zeolit alam (Si-O-Al) dengan atom $\mathrm{H}$ pada residu asam amino (-COOH) (Sari et al., 2014). Hasil penentuan persentase enzim loading ditunjukkan pada Gambar 1.

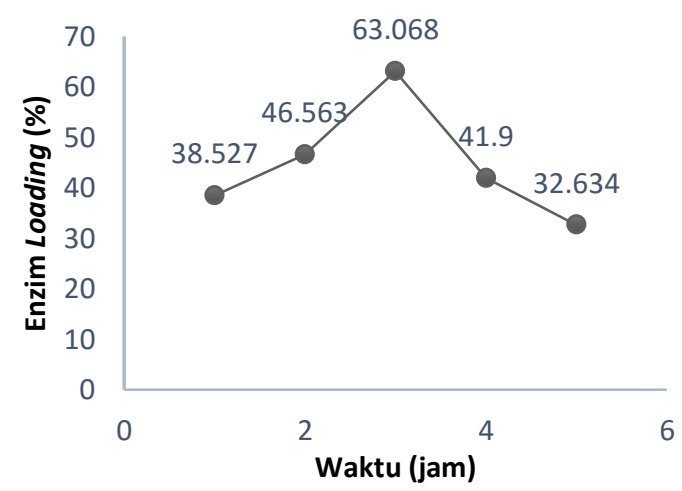

Gambar 1. Hasil penentuan enzim loading pada variasi waktu pengadukan

Jumlah enzim lipase yang terjerat dalam matriks zeolit semakin meningkat dengan bertambahnya waktu pengadukan sampai pada waktu optimum yaitu 3 jam dengan persentase enzim loading sebesar 63,07\%. Peningkatan persentase enzim loading dapat dikaitkan dengan interaksi antara enzim lipase dengan matrik yang digunakan semakin lama akan semakin kuat ikatannya (Sari et al., 2014), sehingga pada waktu pengadukan optimum enzim lipase diperkirakan terjerat sempurna dalam matrik tersebut. Namun demikian, pada pengadukan lebih dari waktu optimum terjadi penurunan enzim loading. Kemungkinan yang terjadi ialah enzim lipase mengalami tingkat kejenuan pada waktu pengadukan selama 4 jam dan 5 jam, dimana laju adsorpsi yang dihasilkan akan sama dengan laju desorpsi sehingga enzim lipase akan terlepas kembali dari pori-pori zeolit.

\section{Sintesis Ester-C secara Berulang}

Sintesis ester-C dilakukan melalui reaksi transesterifikasi antara asam askorbat (vitamin C) yang bertindak sebagai alkohol 
dan suatu ester yang berasal dari minyak VCO. Reaksi yang terjadi ditunjukkan pada Gambar 2.
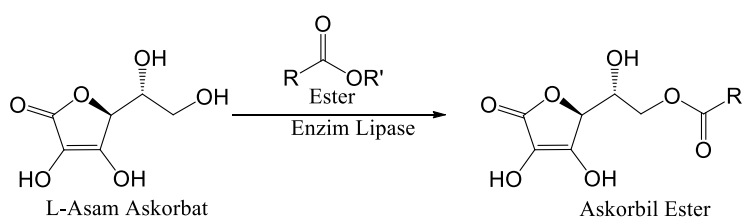

Gambar 2. Reaksi transesterifikasi dalam sintesis ester-C

Reaksi transesterifikasi yang terjadi pada sintesis ester-C. Laju asilasi yang terjadi bergantung pada halangan sterik dalam suatu alkohol yang digunakan.Asam askorbat mempunyai empat gugus - $\mathrm{OH}$, dimana salah satunya merupakan alkohol primer. Secara umum, Karmee (2011) menyatakan bahwa laju esterifikasitransesterifikasi paling cepat pada penggunaan alkohol primer, karena mempunyai reaktivitas yang paling tinggi pada reaksi esterifikasi-transesterifikasi, sehingga alkohol primer tersebut yang menyerang karbon positif dari suatu ester. Selanjutnya pada reaksi tersebut akan mengalami eliminasi ROH dan akan membentuk suatu ester baru yang dituju, yaitu ester-C (ascorbyl ester).Hubungan antara uji stabilitas enzim secara berulang dengan persentase konsentrasi ester-C disajikan pada Gambar 3.

Enzim lipase terimobilisasi dapat digunakan secara berulang-ulang dalam reaksi transesterifikasi pada sintesis esterC. Hal ini menunjukkan bahwa enzim lipase terimobilisasi mampu mempertahankan aktivitas katalitiknya pada penggunaan sebanyak tiga kali pengulangan. Meskipun demikian, ester-C yang diperoleh menunjukkan adanya penurunan persentase area.Kemungkinan yang terjadi ialah adanya kontaminasi substrat yang mengakibatkan enzim lipase mengalami kerusakan, dapat pula disebabkan karena konsentrasi enzim yang bereaksi pada penggunaan selanjutnya sudah berkurang. Selain itu, Hasanah and Putra (2009) menyatakan bahwa proses penyimpanan enzim lipase terimobilisasi dapat mempengaruhi aktivitas katalitik. Hal ini disebabkan oleh adanya pelepasan enzim selama masa penyimpanan berkaitan dengan temperatur maupun $\mathrm{pH}$ yang tidak konstan dan perbedaan waktu penyimpanan.

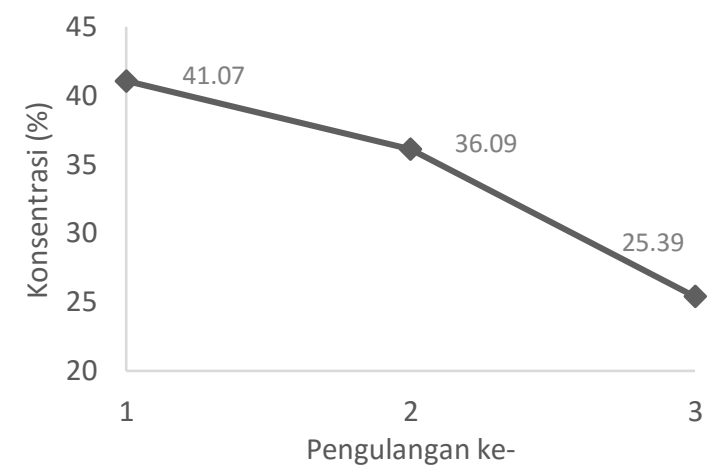

Gambar 3. Hubungan antara uji stabilitas enzim secara berulang dengan persentase konsentrasi ester-C.

\section{Analisis FT-IR}

Analisa FT-IR dilakukan untuk mengetahui adanya gugus fungsi yang terdapat pada senyawa hasil sintesis esterC. Hasil spektra IR pada asam askorbat sebagai bahan awal dan hasil sintesis ester$\mathrm{C}$ ditampilkan pada Gambar 4.

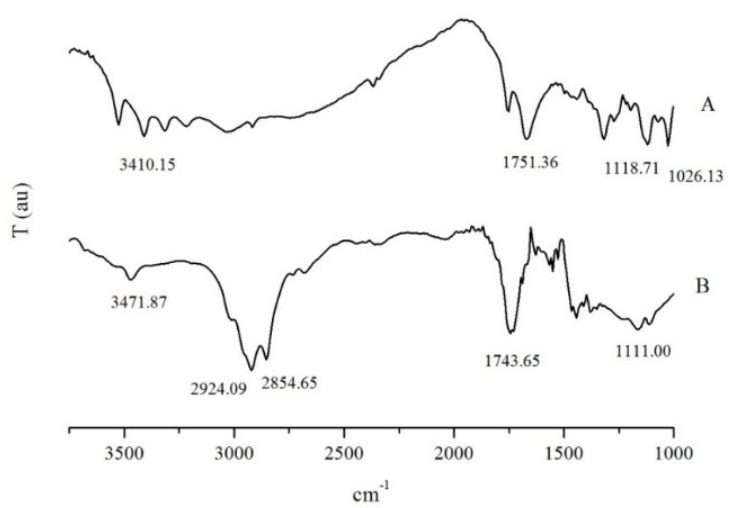

Gambar 4. Spektra IR dari (A) asam askorbat dan (B) hasil sintesis ester-C

Karakterisasi gugus fungsi pada asam askorbat ditunjukkan dengan adanya serapan puncak yang menunjukkan alkohol primer dan puncak regangan $\mathrm{C}-\mathrm{O}$ alkohol. Menurut Panicker et al. (2005), pada spektrum IR asam askorbat terdapat puncak gugus $\mathrm{O}-\mathrm{H}$ yang membentang dikarenakan 
adanya kelembaban dalam sampel yang digunakan. Serapan puncak $\mathrm{C}=\mathrm{O}$ yang muncul dimungkinkan adanya gugus ester dalam senyawa tersebut. Hal ini ditunjukkan adanya perbedaan antara spektrum IR asam askorbat (vitami C) dengan hasil sintesis.

Berdasarkan interpretasi data spektra IR pada hasil sintesis ester-C diduga terdapat perbedaan dengan spektrum IR pada asam askorbat. Spektrum hasil sintesis ester-C menunjukkan adanya regangan $\mathrm{C}-\mathrm{H} \mathrm{sp}^{3}$, yang diperkuat dengan adanya puncak regangan $\mathrm{C}-\mathrm{H}$. Sedangakan pada spektrum asam askorbat tidak menunjukkan adanya puncak yang sama.Hal ini dikarenakan terjadi peningkatan jumlah streching $\mathrm{C}-\mathrm{H}$ $\mathrm{sp}^{3}$ pada ester $\mathrm{C}$ dibandingkan asam askorbat.

Puncak khas gugus alkohol pada hasil sintesis ester-C dapat dilihat menunjukkan adanya perbedaan. Pada hasil sintesis ester$\mathrm{C}$ menunjukkan puncak regangan gugus $\mathrm{O}$ $\mathrm{H}$ dan puncak regangan $\mathrm{C}-\mathrm{O}$ yang terikat pada alkohol terdapat pada bilangan gelombang $1111 \mathrm{~cm}^{-1}$ yang menunjukkan adanya alkohol sekunder. Hasil spektrum IR ester-C tidak menunjukkan adanya gugus $\mathrm{C}-\mathrm{O}$ yang terikat pada alkohol primer, yaitu pada bilangan gelombang $1075-1000 \mathrm{~cm}^{-1}$. Hal ini dikarenakan pada reaksi transesterifikasi, gugus alkohol primer pada senyawa asam askorbat akan berikatan dengan suatu ester dari minyak VCO menjadi senyawa ester-C, sehingga pada senyawa ester-C tidak mengandung alkohol primer. Berdasarkan hasil perbandingan interpretasi spektra IR disimpulkan bahwa pada reaksi transesterifikasi menghasilkan senyawa ester-C.

\section{Analisis HPLC}

Standar yang digunakan pada penelitian ini ialah larutan standar Asam Askorbat (Vitamin C) dan Ester-C holisticare yang telah diekstrak. Hasil kromatogram larutan standar ditunjukkan pada Gambar 5. Menurut Erviana et al. (2013), puncak ester-C akan muncul lebih lama dibandingkan dengan puncak asam askorbat, hal ini berkaitan dengan perbedaan titik didih kedua senyawa tersebut. Puncak identifikasi asam askorbat muncul pada waktu retensi 2,41 menit Sedangkan hasil kromatogram dari holisticare Ester-C yang telah diekstraksi menunjukkan puncak pada waktu retensi 2,66 menit, dimana puncak tersebut merupakan puncak identifikasi dari asam askorbat. Puncak pelarut kloroform diketahui muncul pada waktu retensi 3,41 menit dan puncak yang diduga merupakan ester-C muncul pada waktu retensi 6,37 menit. Adapun hasil kromatogram pada sintesis ester-C disajikan pada Gambar 6.

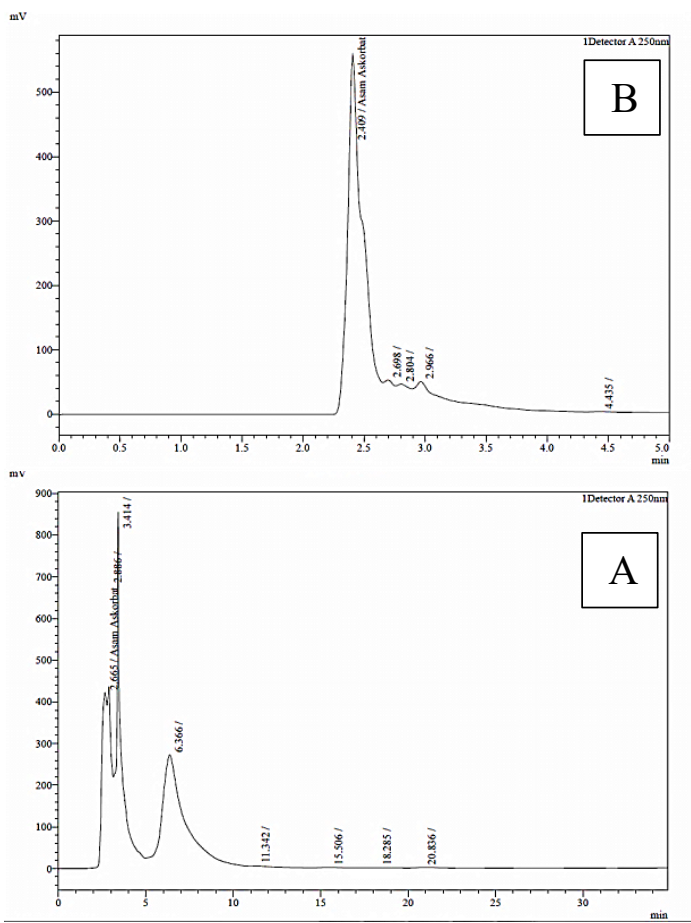

Gambar 5. Hasil kromatogram standar (A) Asam askorbat dan (B) Ester-C holisticare

Hasil kromatogram pada Gambar 6 menunjukkan puncak pada waktu retensi 2,46 menit yang diketahui merupakan puncak senyawa asam askorbat. Puncak senyawa ester-C dari hasil sintesis diduga muncul pada waktu retensi 6,63 menit. Sintesis ester-C pada penelitian ini dimungkinkan menghasilkan suatu senyawa yang mirip dengan senyawa yang terkandung dalam holisticare Ester-C, dibuktikan dengan terbentuknya puncak 
yang muncul pada waktu retensi sekitar menit ke-6.

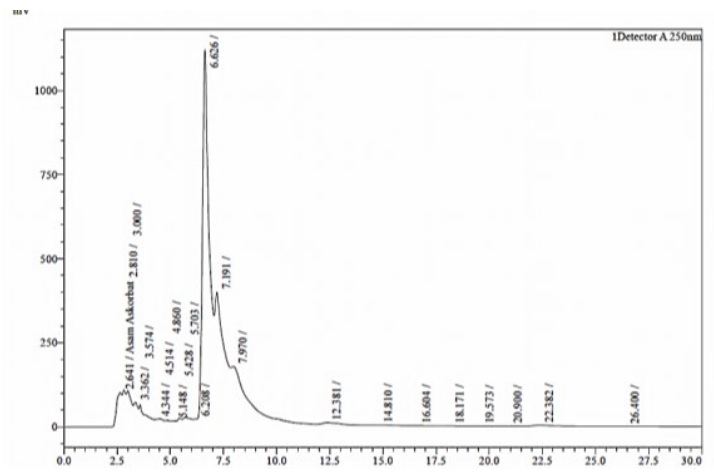

Gambar 6. Hasil kromatogram pada hasil sintesis Ester-C

\section{Kesimpulan}

Imobilisasi enzim lipase secara entrapment menggunakan zeolit alam dapat digunakan sebagai biokatalis dalam sintesis ester-C pada penggunaan berulang sebanyak tiga kali. Pada waktu pengadukan imobilisasi enzim lipase selama 3 jam menunjukkan waktu yang paling optimum dengan nilai aktivitas lipase sebesar 4,24 U/ $\mathrm{mL}$ dan persentase enzim loading sebesar $63,07 \%$.

\section{Daftar Pustaka}

Amalia, R., Rumondang B. dan Firman S. (2013). Penetuan pH dan Suhu Optimum untuk Aktivitas Ekstrak Kasar Enzim Lipase dari Kecambah Biji Karet (Hevea brasiliensis) terhadap Hidrolisis PKO (Palm Kernel Oil), Jurnal Saintia Kimia, 1(2).

Costa, I. C. R., Sutili, F. K., Da Silva, G. V. V, Leite, S. G. F., Miranda, L. S. M. and De Souza, R. O. M. A. (2014). Lipase catalyzed ascorbyl palmitate synthesis under microwave irradiation, Journal of Molecular Catalysis B: Enzymatic, 102, 127-131.

Eitenmiller, Ronald, R. and Landen, W. O. (2010). Vitamin Analysis for the Health and Food Sciences, London: CRC Press.
Erviana, W., E. Kusumo dan Supartono. (2014). Sintesis Ester-C melalui Reaksi Transesterifikasi dengan Katalis Enzim Lipase, Indonesian Journal of Chemical Science, 3, 203 206.

Hasanah, Elok N.I. dan Putra, S. R. (2009). Karakterisasi Ekstrak Kasar Enzim Invertase yang Diamobilisasi dengan Na-Alginat, Prosiding Skripsi, SK-08. Surabaya: FMIPA, Institut Teknologi 10 Nopember.

Karkhane, A. A., Yakhchali, B. Jazli, F. R., Hemmat, J., Shariati, P., Khodabandeh, M. and Zomorodipoor, A. (2012). Periplasmic Expression of Bacillus thermocatenulatus Lipase in Escherichia coli in Presence of Different Signal Sequences, Iranian Journal of Biotechnology, 10(4) 255 262.

Karmee, S. K. (2011). The Synthesis, Properties, and Applications of Ascorbyl Ester, Lipid Technology, 23, $227-229$.

Kidwai, M., Mothsra, P., Gupta, N., Kumar, S. S. and Gupta, R. (2009). Green Enzymatic Synthesis of L-Ascorbyl Fatty Acid Ester: An Antioxidant. Synthetic Communications, 39, 1143 1151.

Nisha, Arun K. and Gobi N. (2012). A Review on Methods, Application and Properties of Immobilized Enzyme, Chemical Science Review and Letters, $1,148-155$.

Panicker, C.Y., Varghese, H.T. and Philip, D. (2005). FT-IR, FT-Raman and SERS Spectra of Vitamin C. Spectrochimica Acta Part A, 65, 802 804.

Parthu, R. D. (2012). Sintesis Biodiesel Rute Non Alkohol dari Minyak Goreng dengan Biokatalis Terimobilisasi Entrapment pada Reaktor Batch dan Reaktor Packed Bed, Skripsi, Fakultas Teknik, Universitas Indonesia. 
Sari, I.P., Sutrisno and Sasangka P. (2014).

Optimasi Amobilisasi Xilanase dari ITrichoderma viride dengan Matriks Zeolit, Kimia Student Journal, 2, 421 427.

Song, Q. X. and Wei, D. Z. (2002). Study of Vitamin C Ester Synthesis by Immobilized Lipase from Candida sp., Journal of Molecular Catalysis B: Enzymatic, 18, 261 - 266.

Spiclin, P., Gasperlin M. and Kmetec, V. (2001). Stability of Ascorbyl Palmitate in Tropical Microemulsions. International Journal of Pharmaceutic, 222, $271-279$.

Treichel, H., Oliveira, D., Mazutti, M. A., Luccio, M. D. and Oliveira, J. V. (2010). A Review on Microbial Lipases Production, Food and Bioprocess Technology, 3,182 - 196. 